\title{
A METHODOLOGY FOR THE CONSERVATION OF SMALL ANATOLIAN CITIES PLANNED BETWEEN 1920 AND 1960
}

\author{
ZEREN ÖNSEL ATALA \& S. YILDIZ SALMAN \\ Department of Architecture, Istanbul Technical University, Turkey.
}

\begin{abstract}
Beginning from the 1960s, cities in Turkey continue dealing with a constant and rapid transformation which causes great pressure particularly for the 20th century and Modernist architectural heritage in those cities. Threat of rapid urbanization is not limited to big cities but also valid for those Anatolian cities planned in between the 1920s and 1960s. The main risk is the limited understanding of integrity and authenticity concepts by decision-makers and planners. For those cities which are visually and aesthetically disowned of a numerous historic layers, they require a careful management of change. The integration of historic preservation with general urban planning decisions is substantial and should aim for the preservation of fundamental, spatial, environmental and social balances. Small Anatolian cities planned between 1920 and 1960 have a significant urban layer dating back to the early 20th century, which forms an integral part of public and urban memory, and the perception of the place. The lack of a systematic legislation and capital based approach supported by authorities especially cause the loss of Modernist architectural heritage. This article aims to propose a methodology for a holistic preservation approach for three cities in west Anatolia, Akhisar, Alaşehir and Tire, where existing features of modern planning period is a part of their authentic character.

Keywords: Anatolian cities, conservation, modern architecture, urban planning.
\end{abstract}

\section{INTRODUCTION}

By the end of the 20th century, modern architecture has been accepted as a significant component of the architectural heritage, yet its conservation is still problematic since this heritage is considered to be particularly vulnerable as a result of weak legal protection and low appreciation among the general public including preservation institutions [1]. The story of international acceptance of the modernist era as heritage goes back to the end of 1980s when DOCOMOMO, the international committee for the documentation and conservation of buildings, sites and neighbourhoods of the modern movement, was founded in 1988 on the belief that the preservation of modern architecture presented an urgent worldwide challenge, one that required the fostering of immediate interaction and collaboration across boundaries. Following the foundation of DOCOMOMO International with Eindhoven Statement in 1990, its subsequent expansions like ICOMOS seminars on 20th-century heritage held in Helsinki and Mexico in 1995 and 1996, and International Day for Monuments and Sites of 2002 dedicated to the 20th-century heritage can be considered as first steps to create an academic awareness on international level.

More recent international documents including the DOCOMOMO Constitution as well as the idea of the spirit of place or genius loci first put forward at the ICOMOS General Assembly Meeting in Quebec in 2008, and the ensuing Valetta Principles for the Safeguarding and Management of Historic Cities, Towns and Urban Areas in 2011 by International Specialists Committee on Historic Towns and Villages of ICOMOS (CIVVIH) incorporate a set of multi-faceted principles and criteria. These principles include both tangible and intangible elements and show a multidisciplinary approach to the historic towns and areas.

As a concurrent contribution to these international documents, the Madrid Document adopted in 2011 again by ICOMOS 20th Century Specialists Committee underlines the 
importance of the modern era as a physical record of its time, place and use as well as its intangible values such as historic, social, scientific or spiritual associations, or creative genius.

At the national level, in Turkey, the heritage protection is regulated with the Law on the Conservation of Cultural and Natural Property, No. 2863/1983, amended several times, that defines cultural property as 'those immovable properties that have been subject to social life in a historic period and has scientific and cultural authentic value' and historic site as 'towns, remnants of towns and those places where cultural properties are concentrated and have been the scene for any kind of social life and/or important historic events, that are the products of various civilizations from the prehistoric period to our day which reflect the social, economic, architectural characteristics of their period', art. 3, amended with Act No. 5226/2004. Hence, there is nothing against the designation of the 20th-century architecture.

The main obstacle against the listing and conservation of 20th-century architecture concerns the criteria of designation. The law includes those buildings constructed 'until the end of the 19th-century' or 'after this date but to be conserved due to their importance and characteristics' according to the Ministry, 'located within a designated site' and 'those buildings and sites which have been the locality of important historic events during the War of Independence and the foundation of the Turkish Republic, and are hence to be documented and registered for their importance in our national history', art. 6. High Council, Principle Decision No. 662/1999, incorporated works built after 1923, clarifying such indecisive and problematic articles, including 'those public buildings used by public institutions and that reflect the architectural characteristics of their period of construction, and those constructed during the first decades of the Republic of Turkey'.

The major legal texts on the conservation of cultural property in Turkey still accept age as an important criterion for national designation. On the contrary, as it can be seen in the international texts, the age value loses its effectiveness as criteria for the evaluation of modern architecture as cultural property. Current approaches in the field of conservation theory suggest not only the preservation of the iconic or singular examples of modern architectural heritage but also the protection of modern implementations as an urban layer. However, most of the buildings and places dating back to recent past are being demolished due to the lack of recognition during urban planning practices, or are at risk of being demolished.

\section{CITY PLANNING PRACTICES IN THE PERIOD 1920-1960}

Spatial organization strategies of the young Turkish Republic can be considered on two levels. First level is the national level, which aims to transform the country into a nation-state, and the second is the reorganization of the cities as the place of modernity. Spatial strategy developed on the national level includes three main elements: leaving Istanbul and constructing Ankara as the new capital city, construction of a railway network expanding to Anatolia and industrial planning for small Anatolian cities which were connected to this railway network [2].

These urban renovation practices in the early years of Turkish Republic were directed by Turkish government as a part of a modernization programme and many legal arrangements were made relating to municipal organizations in cities. Considering the importance of railway network for these redeveloping cities, train stations gained importance in the general urban layout. So the railway stations and the main roads, all of them named Istasyon Caddesi, connecting the stations to city centres were of concern as a primary issue in the new planning decisions and activities. 
In 1924, it was defined that each urban settlement needs to establish a municipal government. In the same year, some additions were made to the applicable legislation with the aim of solving planning issues in Anatolian cities affected by fires. Also in the same period, there were the first attempts to compile a planning literature in Turkish. The first urbanism and municipality journal, Istanbul Şehremaneti Mecmuasl, was first published in 1924, and in 1926 Camillo Sitte's book, Der Städtebau nach seinen künstlerischen Grundsätzen, was translated into Turkish [3]. In 1931, Zeki Sayar, Abidin Mortaş and Abdullah Ziya Kozanoğlu started publishing Arkitekt Magazine. Three years later, in 1934, the Ministry published the first issue of Public Works Journal. In 1935, Osman Nuri Ergin's conference on urbanism in the Institute of Economics and Internal Medicine, which was established in Istanbul University's Faculty of Law, was published as a book called Urbanism in Turkey. This book can be considered as the first thesis produced against the urban models of the West. Publications related to architecture and urban planning that had increased in number by the 1930s have led the discussions in those areas.

In spite of new regulations in the early 1920s, planning activities were far away from being the output of a holistic view. In 1933, it was mandatory to make a city plan within 5 years for every municipality in accordance to the Law on Building and Roads No. 2290 (Fig. 1). The law remained in force till 1956 and gave way to the Building Law No. 6785, with the rapid urban population growth that began in the 1950s and gained momentum in the 1960s [4].

Since Modernism is based on the classification of uses and on the possibility of covering the optimal prerogatives of the principal urban functions both separately and collectively, city
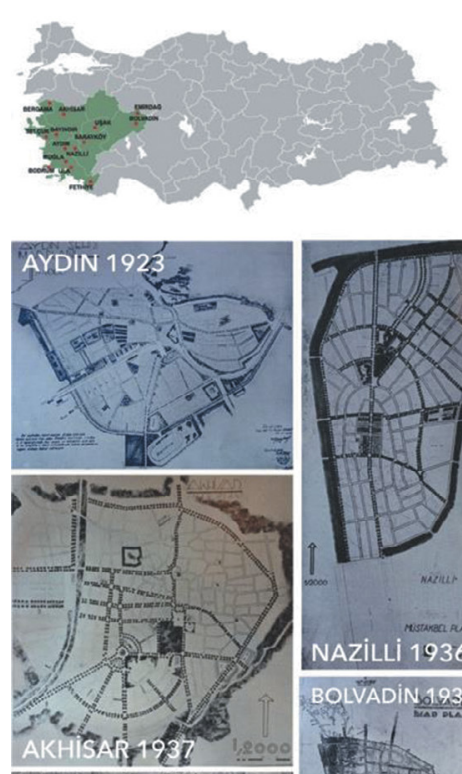

EMIRDAĞ 1946 :

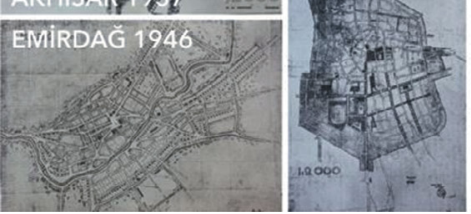

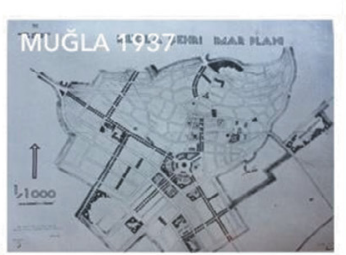
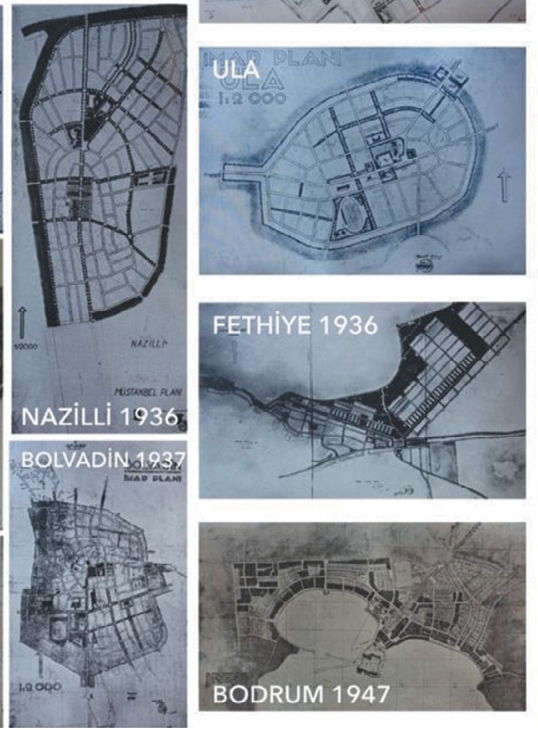
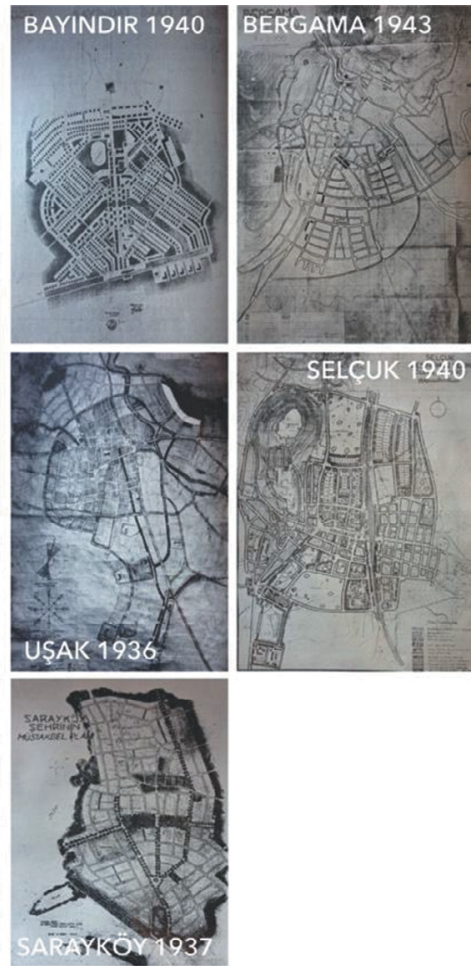

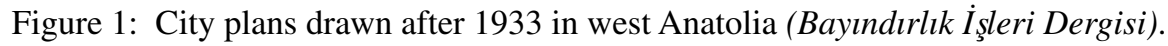


plans prepared after the 1930s mainly aim for an economic and social development as well as creation of modern city spaces. Recreational areas such as city parks, sport fields and wide roads, open spaces, garden and governmental buildings with new functions appropriate to modern city life were tools used to achieve extensive development. In this period, city planning is based on the creation and development of the public spaces in an environment that was to be shaped with the modern life style: public buildings and spaces became the most important elements defining the cities [5].

Importation of modernism in the urban scale via urban planning and urban planners from central Europe to Turkey in the periphery can be clearly seen in the city plans developed after the 1930s, where many European city planners prepared plans for some cities in Turkey. However, the new plans for small Anatolian cities included in this paper were developed by Turkish planners following the same main approach of 'modern urban planning'.

Urban planning activities in the early republican years in Turkey follow the basis created by topographical engineers, who prepared city maps at the end of 19th century during the Ottoman Empire. These planning studies were primarily experienced on areas affected by fires with the general attitude of creating a grid system and the widening of streets.

After the War of Independence, 1919-1922, the population was drastically diminished in the Aegean region and many cities were severely damaged by fires. So planning activities in Alaşehir, Akhisar and Tire were mostly focused on replanning both depicted areas and those affected by fires. In all the above-mentioned cities, the development plans prepared after 1923 stand at a certain distance from existing fabric. With improvements in the idea of functional urban development, needs of a modern society were tried to be satisfied by urban design. So public recreational and cultural places, such as municipality parks, public squares, sport fields, movie theatres, libraries and community halls, were the new urban forms added to the planning knowledge acquired from the Ottoman Empire.

\section{CASE STUDIES}

\subsection{Alaşehir and Akhisar/Manisa}

Alaşehir and Akhisar are both districts of the Manisa Province. Alaşehir, known as Philadephia in Antiquity and in the Middle Ages, situated at the southeast part of Manisa, has a history dating back to the 2nd century BC. In the following periods, as an Ottoman city, mud brick and wooden houses formed the urban character. Galip Bey was the first known mayor of Alaşehir who stayed on task between 1919 and 1923 [6]. In the early years of Republic, after 1923, planning of the areas affected by fire was the main concern of Alaşehir Municipality. Topographical engineers, Sait Erer and Cemalettin, prepared the first urban development plan for Alaşehir in 1924 [7]. This plan mainly focused on the partial widening of roads and settlement of the immigrants of the population exchange between Greece and Turkey [8] (Fig. 2). Because the city was severely damaged by the great fire of Alaşehir in 3-4 September 1922, almost all of urban land was planned in 1924. According to Sungur [9], there were only 6,000 people, 100 houses, 2 mosques and 3 shops left behind from a city of 4,500 houses and with a population of 38,000.

Akhisar is the biggest district of Manisa and is situated at the northern part of the city. The old town of Akhisar is established in a fertile plain of the same name. Even though the municipal council of Akhisar was founded in 1884, the first attempts at urban planning were limited to the construction of immigrant houses in 1924 [10]. At the same period, the municipality was also busy settling the victims of fire that occurred in Manisa. As a result of new needs of modern life, after the proclamation of the Republic, many educational buildings and public spaces for recreation and entertainment were designed (Fig. 3). 


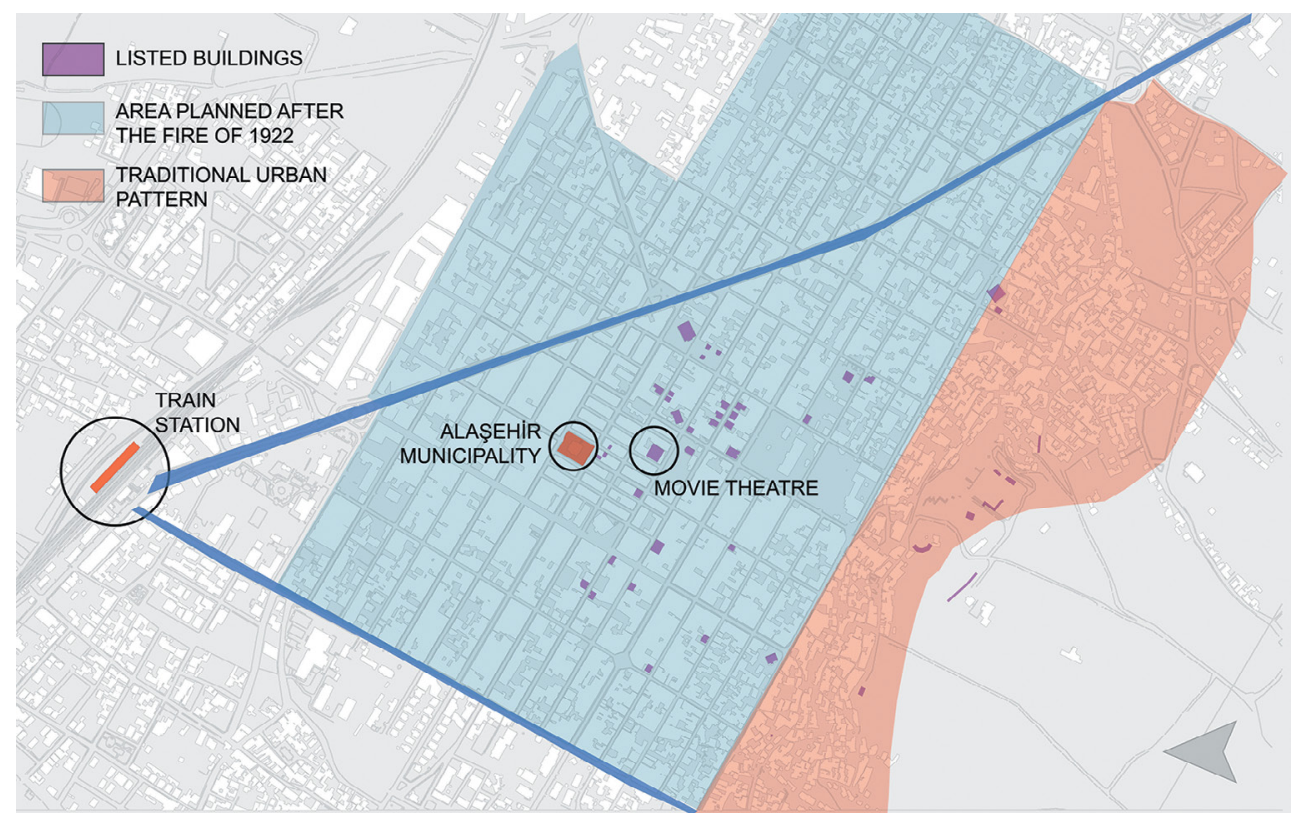

Figure 2: Alaşehir city plan produced from 1/1000 scale city map.

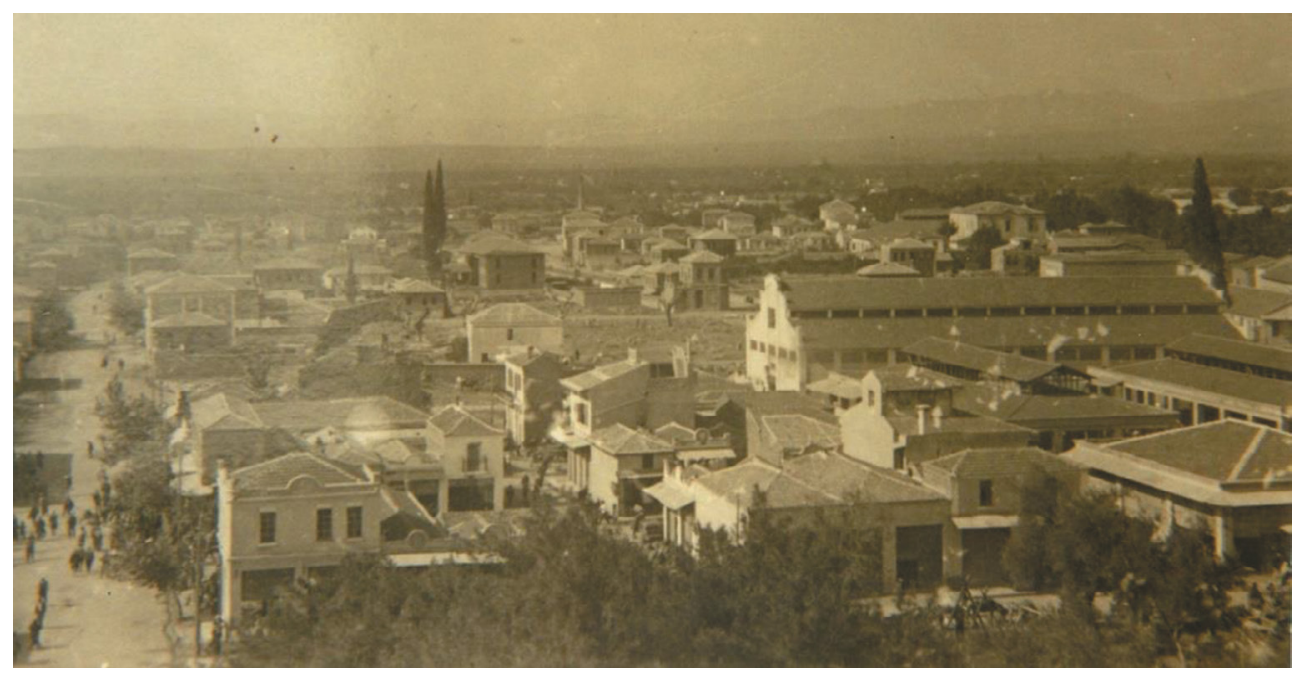

Figure 3: General view of Akhisar between 1930 and 1940s (Anonymous).

Between 1923 and 1933, two primary schools, Misak-ı Milli and Gazi, a library, Zeynelzade, a movie theatre, Tayyare Sineması, a butcher market, Kasap Hali, a hotel, Florya, the municipal garden and many shops were built [11].

The city map prepared by Sait Erer in 1934, and approved three years later in 1937, was covering an area of 180 ha. The urban development plan, on the other hand, was prepared and approved the same year by the Urban Planning Scientific Committee within the Ministry of Public Works [12]. The urban development plan predicts an expansion of city boundaries to the west and south. 

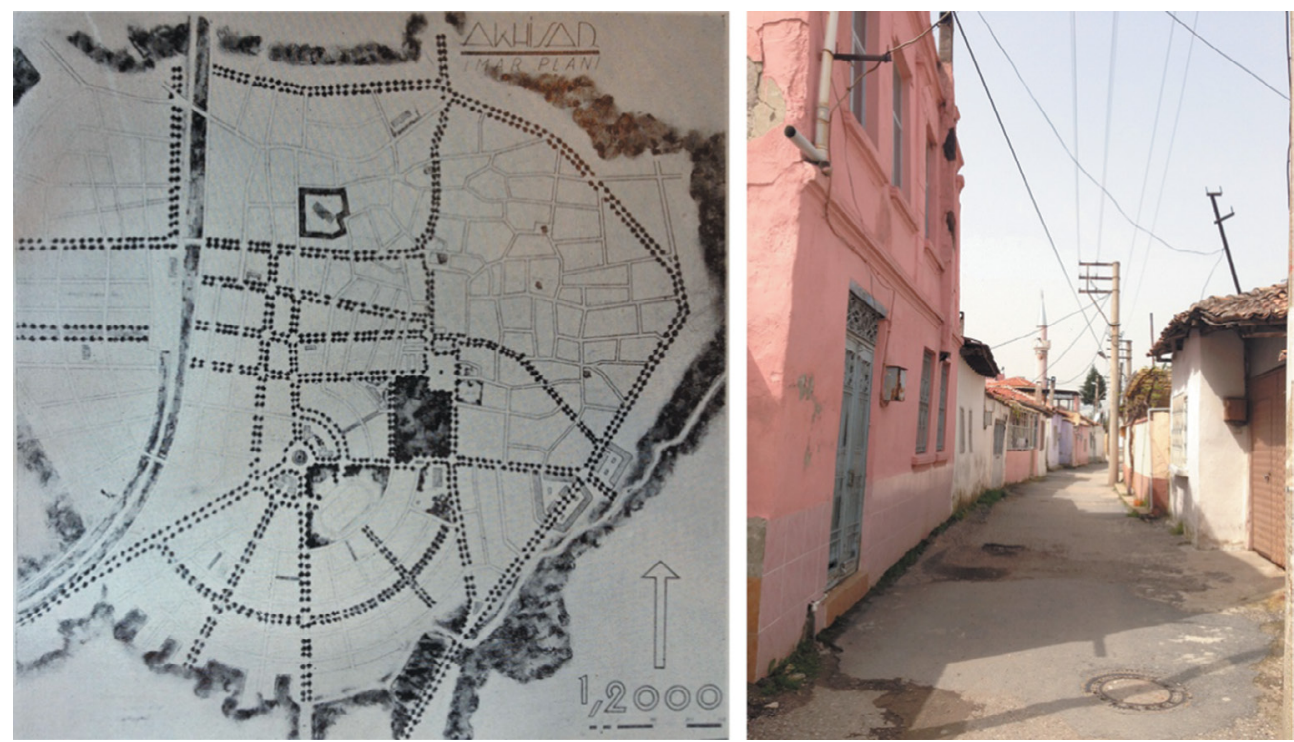

Figure 4: (a) Plan of Akhisar by Sait Erer; (b) Traditional housing pattern of Akhisar.

The urban fabric that remains at the eastern part of Akhisar, mostly consisting of houses, is preserved with its street pattern (Fig. 4). Monuments like public baths and mosques dating back to the Ottoman Empire are preserved as well. The urban development plan does not include the reorganization or rehabilitation of the old centre, but it proposes a new parcelling in the mainly agricultural areas.

\subsection{Tire/Izmir}

Tire is a district of the Izmir Province and is located at the southeast border of the city. The old town of Tire leans adjacent to the Güme Mountains in the south and against the Küçük Menderes Basin in the north. The town is planned along two main axes: Selçuk-Ödemiş highway on the east-west direction and Izmir-Bayındır-Ödemiş highway on the north-south direction. The urban pattern and architectural character of the area remaining at the southern part of Selçuk-Ödemiş highway mainly represents a typical west Anatolian city with traditional houses, while the area on the northern side was mainly planned after 1920s.

Throughout history, many earthquakes and fires have occurred in Tire that shaped its urban morphology. The earthquakes that had destructive effects for the city are the ones that happened in 23 February 1653, 1850, 1880 and 31 March 1928 [13]. The fire that occurred on 2 July 1916 affected the city centre severely with a complete loss of 2,000 houses and 450 shops [14].

The first urban planning attempts in Tire starts in the 1910s: according to the local newspapers, two French engineers, called Aleko and Ikar, prepared the first city plan in 1912. However, the commercial centre consisting of perpendicular roads and a grid plan scheme, gains its urban fabric after the big fire of 1916 with the reconstruction of the damaged area (Fig. 5). There is no information on any planning work after the fire. However, it is known that many public buildings have been constructed since the first years of the Republic. 


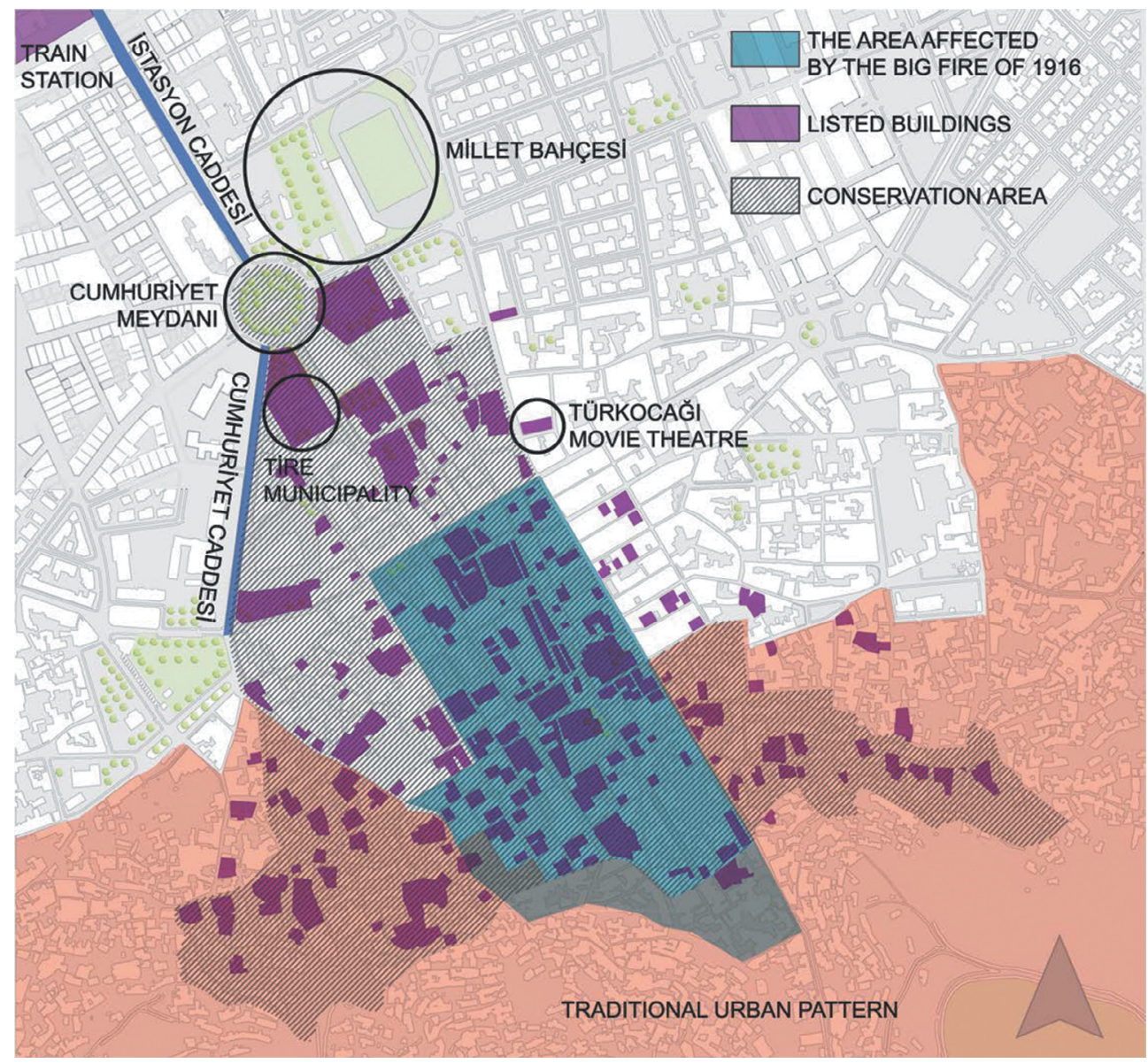

Figure 5: Tire city plan produced from 1/1000 scale city map.

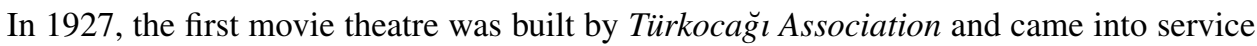
the same year. In 1930, a public recreational area, Millet Bahçesi, was planned in the backyard of Girls' Vocational School and in 1933, the government office was built at the core of Tire. Between 1934 and 1940, many urban open spaces serving modern city life were organized. The park within train station, the main public square called Cumhuriyet Meydanı and the wide boulevard connecting the old Tire to the train station, Istasyon Caddesi, were opened in this period.

Vedat Erer prepared the first urban development plan for Tire in 1950. Using the grid scheme, Erer's plan consisted of wide boulevards and reorganized the urban pattern. The development plan was implemented under the supervision of Can Egeli, who worked in Tire Municipality between 1952 and 1955, and was also the architect of many public buildings and projects that were realized in the same period [15]. The plan included rehabilitation of certain areas and new construction activities.

Considering the existing character of the city, the plan proposed three different interventions for the city such as new parcelling for the area at the northern side of public square and for some areas in Istasyon and Cumhuriyet streets; preservation of residential fabric on both 


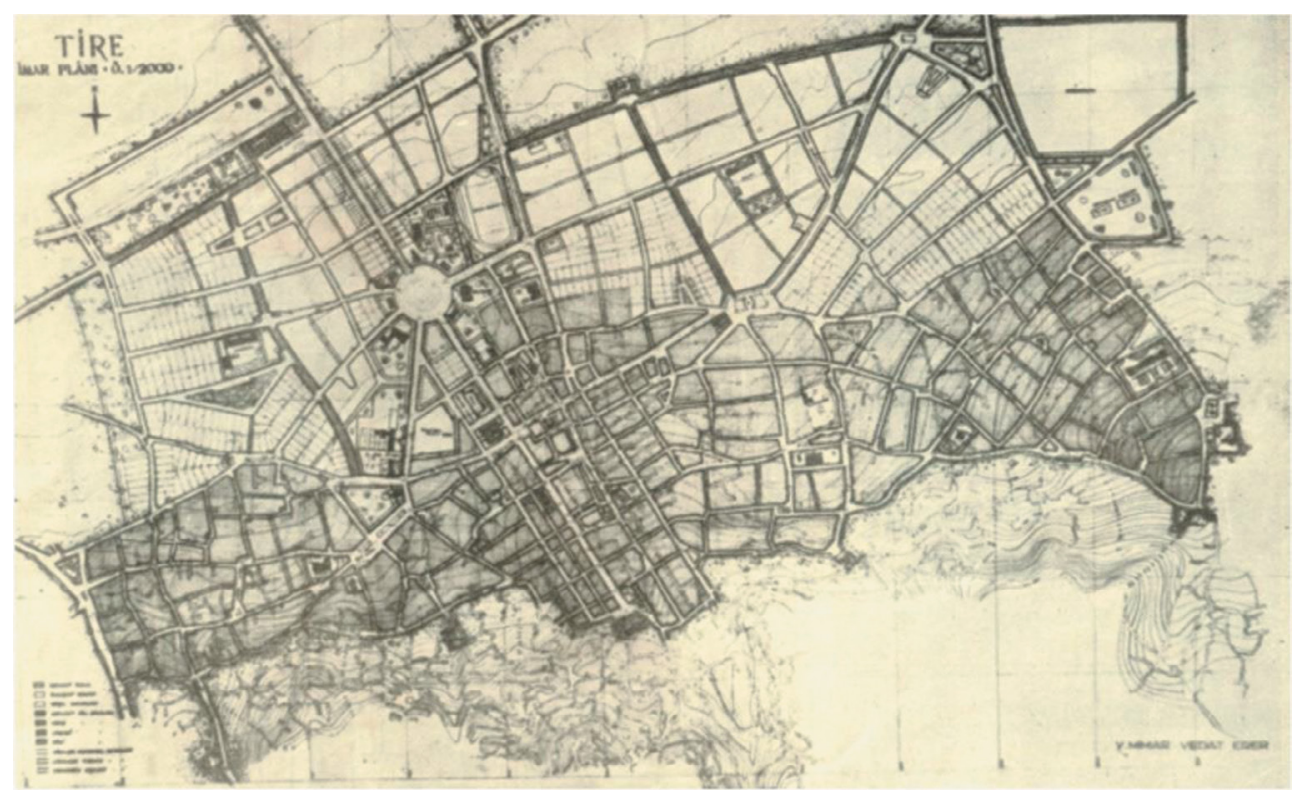

Figure 6: Tire urban development plan of Vedat Erer (Beş Yllda Tire: 1950-1955).

the sides of the commercial centre; and the demolition and rebuilding of some existing structures in the commercial centre (Fig. 6).

\section{CURRENT SITUATION AND THREATS}

Three small Anatolian cities Akhisar, Alaşehir and Tire, studied in this article, still have considerably important physical features of modernist period including urban pattern and open spaces besides public and residential buildings. However, the current planning practices in these cities appear as a serious risk for the recent past (Fig. 7). The main problem for preservation is the legal acceptance of modern heritage. Unfortunately, conservation plans do not consider the historical importance and preservation values of the areas planned between 1920 and 1960 (Fig. 8).

In Alaşehir, the only conservation plan is prepared for the ancient city of Philadelphia in 2014 , yet, there is no conservation plan developed for the city centre.

The conservation plan of Akhisar was approved in 28 October 2011 by Izmir No II Regional Commission on the Conservation of Cultural and Natural Property (RCCCNP). However, this plan does not have a holistic view for the urban features of modernist period of the city, but considers some of the iconic examples of that period such as the movie theatre, Tayyare Sinemasl, or butchers' market, Kasap Hali, as properties to be preserved.

In the case of Tire, urban preservation site borders are defined by Izmir RCCCNP No II in 2009 and the conservation plan was approved by the same commission in 2010. The buildings of the modernist period were not even included in the historical development chapter of the plan report. The residential buildings and commercial areas constructed after the plan in 1950 were misclassified as examples of an architectural period between 1940 and 1950.

All the case studies briefly discussed within this study have urban patterns formed in the period following the foundation of the Turkish Republic up to the 1950s. The urban layers of 

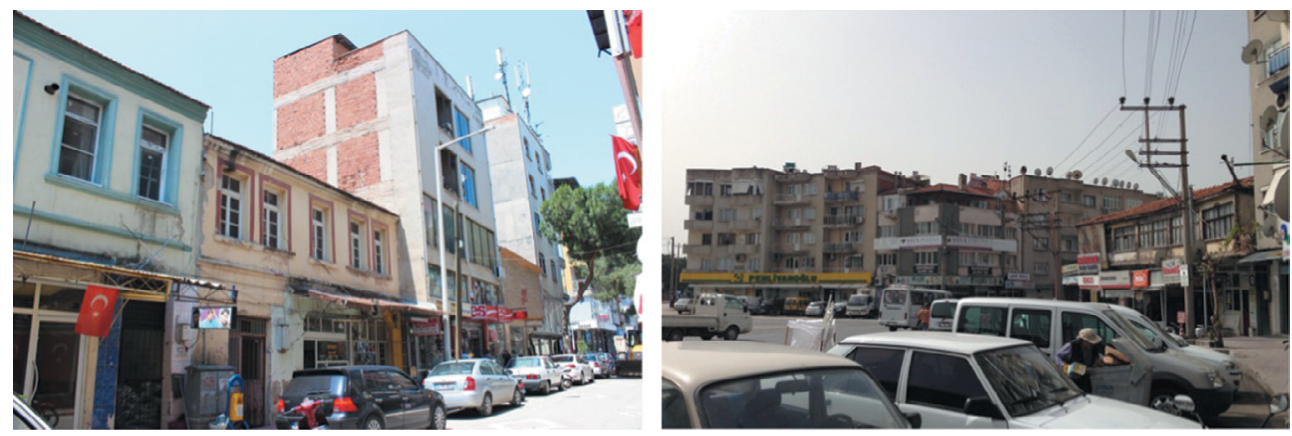

Figure 7: (a) View of commercial centre of Alaşehir, 2014; (b) Akhisar city centre, 2013.
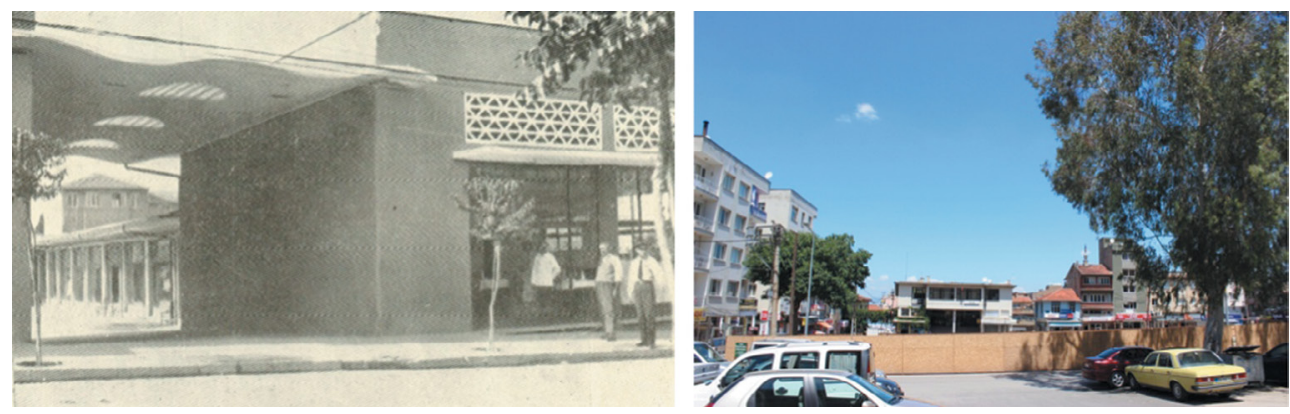

Figure 8: (a) Market building of 1950s, Tire; (b) The same building demolished in 2014.

this recent past have a range of values such as, design value, memory value, historical value and social value contributing to the historical character of the site.

\section{CONCLUSION}

It is clear that the concepts of modernism have had an indisputable impact on the image and structure of the cities all over the world. One of the main reasons of cursing the modernist period of the historical settlements is the so-called destructive planning approach of the period which caused major or partial transformations in the urban pattern. However, with the acceptance of the modern architectural heritage values and expanded redefinition of authenticity and integrity, many international texts today underline the importance of preserving all historical layers, considering both tangible and intangible values.

According to Valletta Principles, the tangible elements include 'the urban structure, architectural elements, the landscapes within and around the town, archaeological remains, panoramas, skylines, view-lines and landmark sites' and the intangible 'activities, symbolic and historic functions, cultural practices, traditions, memories, and cultural references that constitute the substance of their historic value'.

As a recent international instrument, the Madrid Document [16] states that the integrity of the architectural heritage of the 20th century should not be impacted by unsympathetic interventions and the value of significant layers of change and the patina of age should be respected. Undoubtedly, this remark should also be considered for urban scale preservation practices. 
In Turkey, the ongoing loss of modern layers bases on both the lack of integrated conservation approach in which conservation planning is accepted as an integrated part of urban planning activity, and the disapproval of the 20th century and modern architectural heritage as an integral part of historical urban layers to be preserved [17]. As the recognition of different preservation values of an urban fabric is a must for a successful urban conservation [18], it is crucial that the significant modern architectural layer should be included in urban conservation planning.

Today, the concept of planning is enlarged into 'management', which includes all related 'legislative, financial, administrative and conservation documents as well as conservation and monitoring plans', embracing the idea of transformation and proposing to make use of it for improving 'the quality' of cultural and architectural heritage. Thus, the methodology for such multi-layered urban areas can only be based on legal recognition and acceptance of all layers. The content of current legislation for the preservation of cultural heritage should be updated to include internationally and scientifically approved heritage values, concepts and time frames. Unless then an entire documentation that is a critical tool for heritage conservation and legal designation of modern heritage depending on scientific evaluation can be possible.

On the other hand, considering the power of public memory and communal value, the replacement of top-down planning approach with a bottom-up format which allows the participation of local bodies and non-governmental organizations will have a constructive effect on the public awareness and acceptance of the cultural heritage values of our recent past.

\section{ACKNOWLEDGEMENT}

This paper has been developed from the ongoing Ph.D. thesis titled '1920-1960 Arast Dönemde Planlanan Batı Anadolu Yerleşimlerinin Kültürel Miras Değerlerinin İrdelenmesi' by Zeren Önsel Atala.

\section{REFERENCES}

[1] Yöney, N.B., Salman, Y.S., Polat, E.O., Turchia, Maledetti Vincoli; La Tutela dell'Architettura Contemporanea Parte Seconda, ed. U. Carughi \& M. Vione, Umberto Allemandi \& C.: Turin, London, Venice, New York, pp. 366-368, 2012.

[2] Tekeli, İ., Türkiye'de cumhuriyet döneminde kentsel gelişme ve kent planlaması, 75 Yılda Değişen Kent ve Mimarlık, ed. Y. Sey, Tarih Vakfı Yayınları: İstanbul, p. 4, 1998.

[3] Tekeli, İ., Türkiye'de Kent Planlaması Düşüncesinin Gelişimi. Yapı, 291(2), pp. 37-41, 2006.

[4] Işık, Ş., Urbanisation and Urbanisation Models in Turkey. Aegean Geographical Journal, 14, pp. 57-71, 2005.

[5] Keskinok, H.Ç., Urban planning experience of Turkey in the 1930s. METU Journal of the Faculty of Architecture, 27(2), pp. 173-188, 2010. DOI: 10.4305/METU.JFA.2010.2.9

[6] Alaşehir'in İdari Tarihçesi. Dünden Bugüne Alaşehir, Alaşehir Kaymakamlığı, pp. 67, 164, Manisa, Turkey, 1985.

[7] Bayındırlık İşleri Dergisi, vol. 5, no. 5, Bayındırlık Bakanlığı, pp. 239-242, 1938.

[8] Alaşehir Municipality Archive.

[9] Sungur, H.Z., Milli Mücadele'de Alaşehir, pp. 25-27, Anadolu Matbaacılık, İzmir, Turkey, 2007.

[10] Türkiye Cumhuriyeti Başbakanlık Cumhuriyet Arşivi, 272-0-0-11, 17-76-11.

[11] Ayaz, B., Cumhuriyet'in Ilk Ylllarında Akhisar Kazast (1923-1933). MSSc thesis, Manisa, Celal Bayar Üniversitesi, pp. 48, 87-93, 2006.

[12] Belediyeler Dergisi, vol. 3, no. 34, June 1938, Belediyeler Bankası, pp. 47-53, 1938. 
[13] İzmir Ill Ylllı̆̆ 1967, Ege Üniversitesi Matbaası, pp. 107-108, 1969.

[14] Etöz, Z. \& Esin, T., Osmanlı Şehir Yangınları. Tarih ve Toplum Yeni Yaklaşımlar, 14, pp. 9-52, 2012.

[15] Tuna, D., Unutulan Bir Mimar: Can Egeli (1927-1969). Mimarlı, 330, pp. 40-46, 2006.

[16] Madrid Document 2011. The ICOMOS International Scientific Committee for Twentieth Century Heritage Web Site, available at http://www.icomos-isc20c.org/madriddocument/ (accessed 17 January 2017).

[17] Salman, Y., Baturayoğlu, N.B., \& Önsel Atala, Z., A model for an integrated multidisciplinary approach for the preservation of 20th century and modernist architectural heritage. Online Proceedings of Conference Built Heritage 2013, ISBN 978-88-908961-0-1, Politecnico di Milano, Centro per la Conservazione e Valorizzazione dei Beni Culturali, Milano, pp. 297-306, 2013.

[18] Bandarin, F. \& Oers, R.V., The Historic Urban Landscape: Managing Heritage in an Urban Century, Wiley-Blackwell: West Sussex, p. 23, 2012. 